\title{
Research
}

\section{Participation in Teacher Research at a Tertiary Institution in Cambodia}

\author{
Chan Narith Keuk \\ Royal University of Phnom Penh
}

\begin{abstract}
This paper reports an examination of Cambodian ELT teachers' participation in the adoption of research at one tertiary ELT institution in Phnom Penh, the Cambodian capital. The data were drawn from the CamTESOL conference handbooks (2005-2013), journal contents of CamTESOL Selected Papers (20052009) and Language Education in Asia (2010-2013), journal contents and research papers published in the institution's journal (2010-2013), and a teacher research profile survey conducted in 2012 at this institution. The analysis reveals that an increasing number of teachers are involved in doing research, presenting the research at the CamTESOL Conference Series, and publishing research papers in the institution's journal. The analysis also shows that a moderate number of teachers at this institution embrace research as seen through their reported adoption categories of research. The study sheds light on an initiative for developing ELT teacher research to improve professional practices in the institution, in Cambodia widely, and beyond.
\end{abstract}

English language teaching (ELT) in Cambodia has recently increased its momentum in contemporary Cambodian society. Since the 2000s, there are more English language institutes, both public and private, offering English language training to Cambodians across the country, compared to only a few private English language institutes in the 1990s (Clayton, 2006).

Moore and Bounchan (2010) stated that ELT in Cambodia has moved from a status in which Cambodian students were taught by native English-speaker professionals two decades ago to a status in which they are now taught by Cambodian ELT professionals. In a similar vein, English is now spoken among Cambodian people, especially young Cambodians living in urban areas, particularly in Phnom Penh (Moore \& Bounchan, 2010).

Alongside the development of English language education, research practice has been initiated. The practice has involved individual Cambodian ELT teachers, domestic tertiary ELT institutions, and broader ELT settings, that is, the CamTESOL Conference Series (CamTESOL). In addition, the Ministry of Education, Youth and Sports (MOEYS), as indicated in its educational strategic plan for 2009-2013, included a focus on research in tertiary education (Ministry of Education, Youth and Sport, n.d.).

Language Education in Asia, 2015, 6(1), 31-45. http://dx.doi.org/10.5746/LEiA/15/V6/11/A4/Keuk 


\section{Background}

The contextualization of ELT research in Cambodia in this paper is based on the author's experience in working at the institution in this study for about ten years and involvement in CamTESOL presentations as a presenter and observer.

Since the CamTESOL Conference Series was established in 2005, Cambodian ELT teachers have begun to undertake research and present their research outcomes at this conference. To encourage and facilitate research activities, CamTESOL, along with other groups, annually provides research grants to Cambodian teachers (and other Southeast Asian teachers) who have submitted qualifying research proposals. CamTESOL has also organised a series of research workshops to equip those grant recipients with disciplinary research knowledge. Of particular importance, CamTESOL has arranged international mentorship (Mahony, 2011; Moore, 2011b) to help grant recipients undertake research, present the research at the conference, and submit papers to Language Education in Asia (LEiA), and previously between 2005 and 2009, the CamTESOL Selected Papers.

In alignment with the establishment of CamTESOL and in response to the institution's vision to achieve quality ELT education and research in the region, the institution established a research unit in 2007 to initiate research as an innovation in English language education at the institution. To promote teachers' engagement in research, the unit has organized a series of annual workshops, training sessions, and research grants. This research unit has also established an internal journal, the Cambodian Review of Language Learning and Teaching (CRLLT), which publishes research papers in English.

\section{Literature Review}

Teacher research in language teaching emerged in the 1980s (Burns \& Burton, 2008) and has attracted great attention from applied linguists, researchers, and scholars. Recently, various studies have examined teacher research in language teaching: in a global context (Borg, 2009, 2013), in the United States (Freeman, 1998), Australia and New Zealand (Burns \& Burton, 2008), China (Barkhuizen, 2009; Borg \& Liu, 2013; Gao, Barkhuizen, \& Chow, 2011), Vietnam (Pham, 2006), and Cambodia (Moore, 2011a, 2011b). The discussion of teacher research generally focuses on the kind of collaborative inquiry involved (with other teachers and/or external collaborators), aims (Allwright, 2005; Borg, 2010, 2013; Cochran-Smith \& Lytle, 1999), quality of teacher research (Nunan, 1997), and conditions for sustaining teacher research (Allwright, 1997; Borg, 2006). This paper addresses ELT teacher research in relation to Borg's (2010) definition of teacher research in language teaching:

[T]eacher research [is] systematic inquiry, qualitative and / or quantitative, conducted by teachers in their own professional contexts, individually or to enhance teachers' understandings of some aspect of their work, is made public, has the potential to contribute to better quality teaching and learning in individual classrooms, and which may also inform institutional improvement and educational policy more broadly. (p. 395)

Freeman (1998) describes the nature of teacher research undertaken by various novice language teachers in different contexts (from elementary school to adult EFL learning contexts) in the United States. Borg's (2009, p. 368) survey reported important characteristics of research viewed by 505 language teachers from diverse ELT settings. These characteristics include objectivity, hypotheses, statistics, variables, large sampling, large volumes of information being researched, and experiment, all of which indicate that teachers were likely to conceive of 
research as more quantitative than qualitative. The study also reported teachers' conceptions of the benefits research has for improving classroom practice. These reported characteristics are supported by Moore's (2011a) survey of 40 Cambodian ELT teachers, using Borg's (2009) baseline questionnaire.

Freeman (1998) and Hopkins (2007) suggested a variety of data collection instruments that teachers might use to gather information in classroom research activities. The instruments comprise classroom observations, field notes, audiotape recording, student diaries, interviews, discussion, teaching logs, videotape recording and digital pictures, questionnaires, sociometry, documentary evidence, case study, student drawings, stimulated recall, and "mapping 'the process of change' in schools" (Hopkins, 2007, p. 148). Freeman also suggested three data analysis frameworks that teachers might use to analyze information collected through the various techniques mentioned above. The analysis frameworks encompass grounded data analysis, a priori data analysis, and quantitative data analysis. See Freeman (1998) for a detailed explanation about these analysis frameworks.

Taking into consideration Rogers' (2003, p. 12) notion of innovation - "innovation is an idea, practice, or object that is perceived as new by an individual or other unit of adoption," teacher research is an innovation in ELT education in Cambodia. It is therefore important to examine how teachers have adopted this innovation. Moore (2011b), in his observation of the practice of teacher research in Cambodia, asserted some reasons that this practice can possibly grow. These reasons include many Cambodian teachers' interest in doing research to attend international conferences and their aim at building their research capacity and record for pursuing higher education degrees, and tertiary ELT institutions' capacity building (i.e., in order to build institutional status) by way of initiating and promoting research.

Rogers (2003) suggested five adoption categories to describe the different rates that individuals participate in an innovation. These five adoption categories, as displayed in Figure 1, encompass innovators, early adopters, early majority, late majority, and laggards. For the purpose of this study, in the context of ELT teacher research, these adoption categories can be briefly described as follows:

Innovators:

Early adopters: Early majority:

Late majority:

Laggards: initiate and organize ELT research.

immediately adopt research and are engaged in research.

are initially hesitant to do research. It takes them some time to decide to be involved in research.

are uncertain about research. They become involved in doing research only after they have seen other teachers' successful results from being involved in research.

usually resist doing research. They usually perceive themselves as teachers only. 


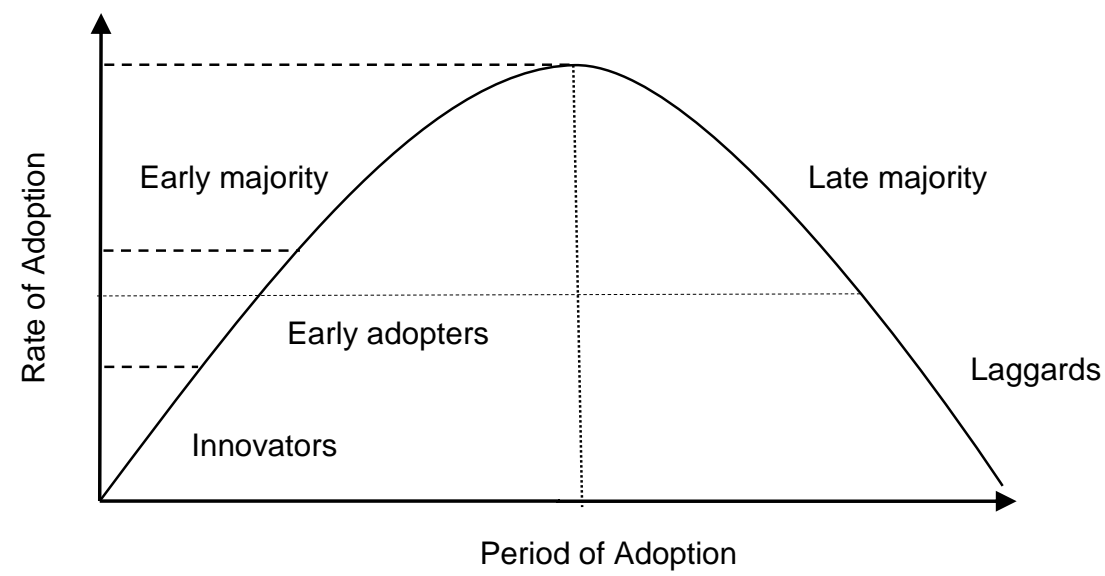

Figure 1. Adoption categories of research, adapted from Rogers (2003).

Figure 1 represents a diffusion of teacher research. According to Rogers (2003, p. 15-16), there are five reasons why the members (ELT teachers) adopt an innovation. These five reasons comprise (1) the great advantages that the innovation provides when adopted; (2) the compatibility of the innovation (the innovation has relevant value, is compatible with the past experience of the adopters, and fulfills the adopters' needs); (3) the trialability (the innovation is experimentable); (4) the observability (the innovation has the potential consequence of being visible to other members); and (5) the complexity (less complicated innovations tend to be adopted more quickly). Given these five factors, research on teachers' participation in research will provide information about success and constraints of implementation of teacher research activities.

Based on Wenger's (2006, p. 1) notion of communities of practice, which is "groups of people who share a concern, or a passion for something they do and learn how to do it better as they interact regularly," ELT teachers' engagement in research is viewed as a process of taking part in research, building relations with other researchers, and joining any institutional research events (e.g., research events organized at CamTESOL and the institution's own research unit). This participation can be primary, peripheral, or marginal (Wenger, 1998). Peripheral teacher researchers (i.e., novice teacher researchers) may move along the trajectory of the participatory process to primary membership. In this regard, teachers are engaged in research because they share a similar concern about undertaking research in classroom to improve the quality of teaching.

This paper, which describes part of a large PhD research project, will examine teachers' participation in research at one tertiary ELT institution in Phnom Penh as response to the innovation of teacher research. That is, it will examine the teachers' engagement in doing research, presenting the research at conferences (i.e., CamTESOL Conference Series), and publishing the research papers. This paper seeks to answer the following questions:

1. To what extent have the institution's teachers been involved in research as evidenced by presentations at the CamTESOL Conference Series and subsequent publication in the CamTESOL Selected Papers (2005-2009), LEiA (2010-2013), or CRLLT?

2. How do teachers self-categorize their engagement in research at this institution?

3. To the extent that teachers have been involved in research,

3.1. What research methods, data collection instruments, and data analysis frameworks did they use?

3.2. Why did they adopt those research methods and data collection instruments? 


\section{Research Methodology}

The research described in this paper is based on data drawn from five sources: (1) CamTESOL conference handbooks (2005-2013); (2) CamTESOL Selected Papers (2005-2009); (3) LEiA (2010-2013); (4) CRLLT (2010-2013); and (5) a survey of teacher research profiles conducted at the institution in this study.

The author examined abstracts accepted by the CamTESOL Conference Series and published in the conference handbooks to identify the institution's teachers who were involved in doing research and presenting it at the conference. The presentations were identified by type: research, paper, workshop, or poster. The CamTESOL Conference Series has recently attracted around 400 international presenters (Mahony, 2011), and in 2013, 376 abstracts were accepted for the conference (CamTESOL, 2013) compared to only 53 abstracts in 2005 (CamTESOL, 2005). Given this rise in the number of abstracts accepted, in categorizing these accepted abstracts in each conference program across nine years, miscounting may occur. Thus, to ensure the reliability of the data, the author went through the accepted abstracts in each annual conference program two times, with a gap of two weeks. For the purpose of this paper, the author only counted the teachers' accepted abstracts for presentations of research papers. The author also examined the teachers' published research papers in the CamTESOL Selected Papers (2005-2009), LEiA (2010-2013) and CRLLT (2010-2013).

The data were also drawn from a survey conducted at the institution to investigate the teachers' participation in research. The survey, based on a questionnaire set, asked the teachers to selfcategorize their adoption of research into one of five adoption categories (i.e., innovators, early adopters, early majority, late majority, and laggards; see the questionnaire in Appendix). The questionnaire, written in English, and an information-and-consent form were distributed to 63 lecturers, both full-time and part-time, in 2012. In that year, 30 teachers were in postgraduate degree programs (i.e., master's or $\mathrm{PhD}$ ) overseas, so the survey only represented the active teaching staff in 2012. Thirty-seven of 63 teachers (58.7\%) signed the information and consent forms, filled in the questionnaires, and put them in the author's pigeonhole in a photocopy room. Of the 37 respondents, the terminal degree for 30 respondents is a master's degree (in TESOL or education), and for seven respondents, a bachelor's degree in teaching English as a foreign language (TEFL).

\section{Findings}

For ease of analysis, the findings are reported for each research question and in three themes: (1) teachers' involvement in teacher research; (2) teachers' adoption category of research; and (3) research methods and data collection instruments that the teachers adopted.

\section{Teachers' Involvement in ELT Research}

Research Question 1 seeks to investigate the extent the institution's teachers have been involved in research by examining participation at the annual CamTESOL Conference and subsequent publication in the CamTESOL Selected Papers, LEiA, or CRLLT.

From 2005 to 2013, 47 teachers gave 94 presentations at a CamTESOL Conference. Of these 94 presentations, 48 were based on research papers, followed by 28 workshops, 11 nonresearch papers, and 7 posters. The examination of the teachers' presentations of research reveals that in general the number of presentations of research increased. As displayed in Figure 2, the number of presentations increased from one in 2006 to nine in 2011 . Researchbased presentations sharply decreased to three in 2012, but recovered to 10 in 2013. 


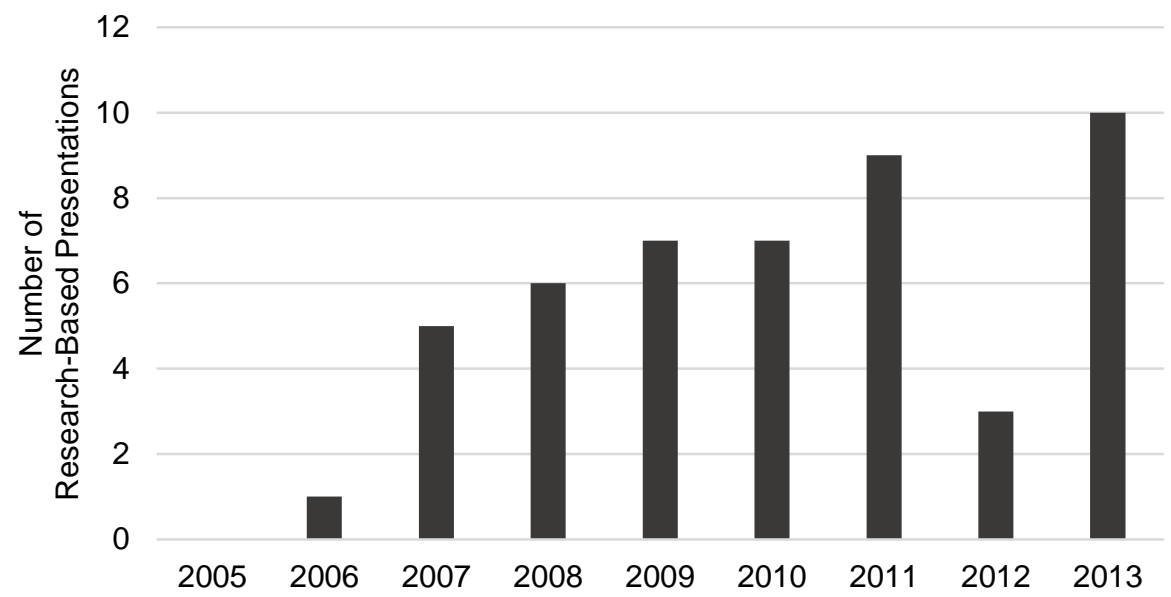

Figure 2. Number of research-based presentations at CamTESOL conferences (2005-2013) by the institution's teachers.

The examination of published papers in the CamTESOL Selected Papers (2005-2009) and LEiA (2010-2013) also revealed a number of papers authored by the institution's teachers. Four research papers authored by teachers were published in CamTESOL Selected Papers (one paper in 2006, two in 2008, and one in 2009), and one paper was published in LEiA, Volume 1, Issue 1 in 2010. In addition, the institution's teachers have published fourteen papers in CRLLT from 2010 to 2013 (five papers in Volume 1, four in Volume 2, and five in Volume 3).

\section{Teachers' Adoption of Teacher Research}

Research Question 2 investigates how teachers have participated in the innovation of teacher research at the institution from 2007 to 2012 . In the teacher research profile survey, the data from the 37 respondents reveals the teachers belong to a variety of categories of adoption of research. As shown in Figure 3, three teachers categorized themselves as innovators, twelve identified themselves as early adopters, ten self-categorized as early majority, and seven saw themselves as late majority adopters. Five other teachers self-categorized as laggards.

Drawing from Rogers' (2003) notion of diffusion of innovation, 25 teachers ( 3 innovators, 12 early adopters, and 10 early majority) might be expected to have embraced teacher research and to have been involved in undertaking research.

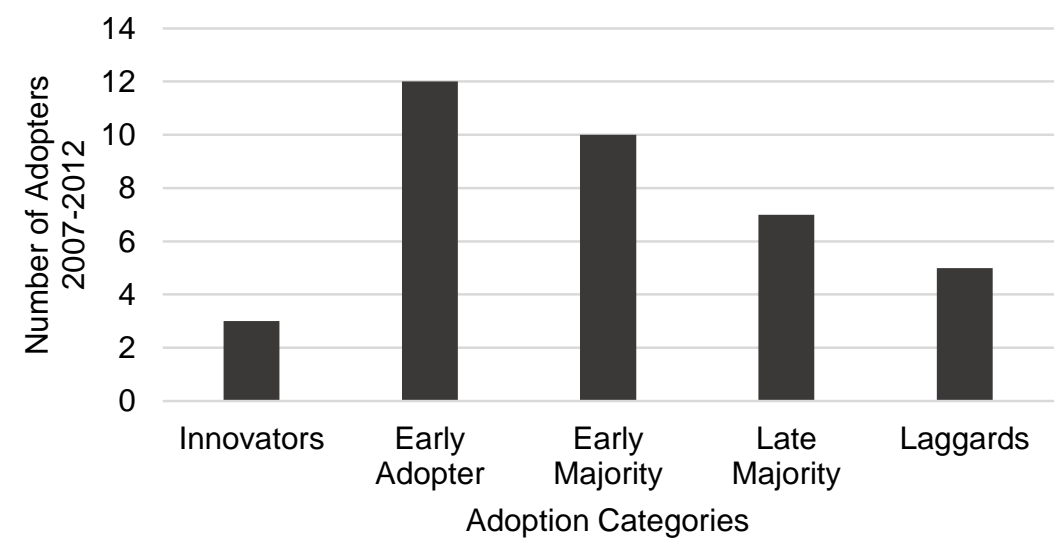

Figure 3. Teachers' self-reported adoption of ELT teacher research. 


\section{Research Methods and Data Collection Instruments}

Research Question 3.1. The data from the teacher profile questionnaires indicate that of the 32 respondents (i.e., those teachers who self-categorized as innovators, early adopters, early majority, and late majority), 27 lecturers reported to have actually undertaken research. The respondents were asked to select research methods provided in the questionnaire to indicate the methods and data collection instruments that they used. The responses show that the most used research approach is a mixed methods approach (55.5\%), followed by a qualitative approach (29.6\%) and a quantitative approach (14.8\%). As illustrated in Figure 4, the most used research instruments are interviews (92.6\%), including semi-structured interviews $(51.9 \%)$, structured-interviews (33.3\%), and unstructured interviews (7.4\%); and questionnaires $(70.4 \%)$. Other reported data collection instruments comprise focus groups $(25.9 \%)$ and classroom observations (14.8\%), followed by narrative frames, fieldnotes, and diary writing (3.7\% each).

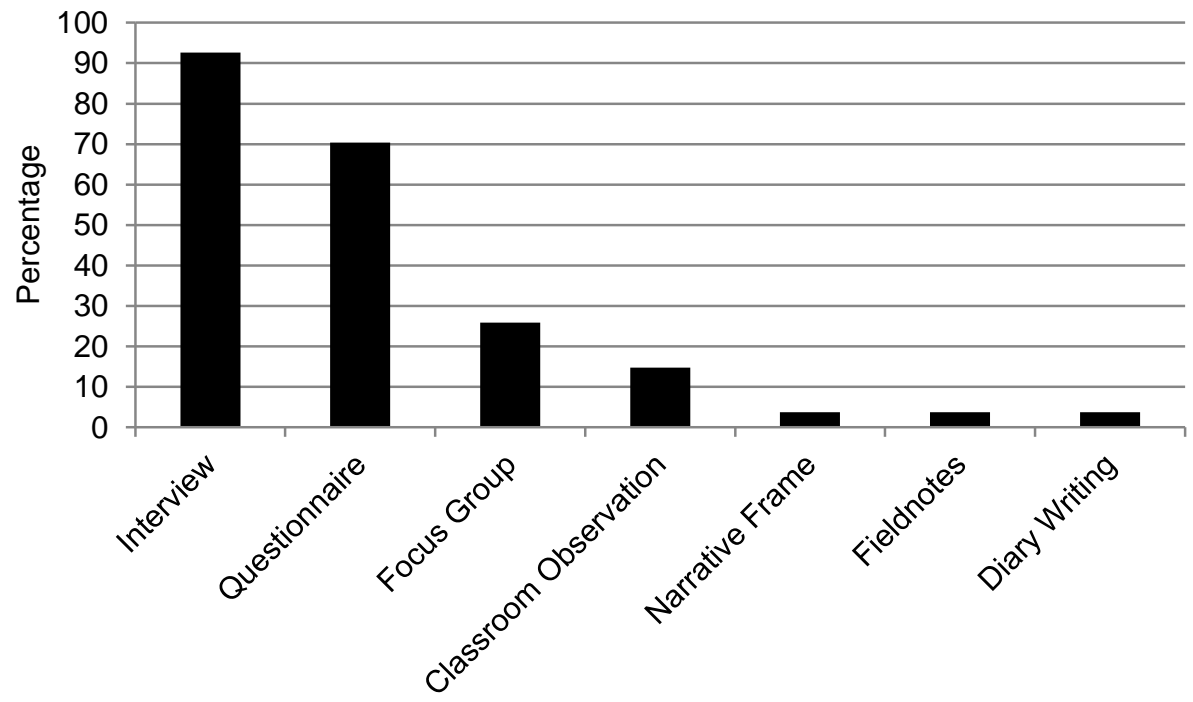

Research Instruments

Figure 4. Teachers' research instruments $(n=27)$.

However, the examination of the 14 papers in CRLLT indicates a slight difference in the data collection instruments from the instruments the survey respondents reported using. Seven papers reveal a quantitative approach by way of administering questionnaires, and two papers indicate a qualitative approach in terms of employment of a focus group and in-depth interviews. Four papers indicate a mixed methods approach, of which two papers used a questionnaire and focus group, the third paper used questionnaire and semistructured interview, and the fourth paper used a questionnaire and think-aloud protocol. One paper analyzed learners' errors. In a similar vein, of the five research papers published in the CamTESOL Selected Papers and LEiA, two papers used questionnaires and three papers analyzed students' written texts; two of these three papers also included interviews.

In addition to the data collection instruments reported to have been used, the analysis also indicates that the majority of papers adopted descriptive statistics to report the research findings. In 11 of the 19 published research papers (in CRLLT, CamTESOL Selected Papers, and LEiA), the authors adopted descriptive statistics for data analysis. One paper used linguistic analysis, and two papers used text analysis. Thus, a moderate number of these published papers shows that a quantitative approach with a questionnaire as an instrument to garner data is 
actually the most used approach and data collection tool, and descriptive statistics is the most used framework for data analysis.

Research Question 3.2. In the last part of the questionnaire, the respondents were asked to express opinions about the research approaches and instruments they adopted for research activities in an open-ended question. For the analysis, the respondents were assigned numbers from L1 to L37. The analysis shows the teachers' selection of certain research approaches and instruments for research projects was influenced by their beliefs about those approaches and instruments. For example, some respondents selected a mixed methods approach because it is a triangulation of research instruments ( 2 respondents) or because it possibly yields more valid and reliable research results (2 respondents). Respondents selected certain approaches and methods because of appropriateness to research topics and questions (9), convenience (4), duration of time spent on research (3), potential for probing rich data (3), and familiarity (2).

As interviews and questionnaires were the research instruments overwhelmingly selected by the respondents, it is worth noting their opinions about these research instruments in their own words:

Semi-structured interviews allowed me to elicit the necessary information to answer my questions. (L18)

From the student interviews, I can get more in-depth understanding and face-toface interaction with my respondents. (L19)

Also, semi-structured interview was used to gain more insight from the participants. (L24)

It [semistructured interview] allows researchers the freedom to tailor their questions to the interview situations and unexpected things that may come up in their mind during the interview. (L31)

As the matter of fact, some of my respondents are educated and [some are] uneducated and illiterate people; therefore, questionnaires were not appropriate for them. (L32)

We only used questionnaires because of time constraints and resources availability. Also it is the easiest means for data analysis. (L5)

It [using questionnaires] is convenient. (L13)

Questionnaire allows me to probe a lot of aspects related to my topic. (L19)

[Questionnaires provide] more accurate data analysis. (L20)

I'm familiar with the use of questionnaire as a tool for data collection the most. (L22)

[Questionnaires can be used] to reach all the participants, especially after their graduation. (L23) 
Questionnaires were used to collect data for my research because the information gained could be transformed into percentage and could be reported as mean, graphs, and tables. (L24)

First, it's convenient. I just placed the questionnaires in the instructors' pigeonholes and went back to collect them. Second, questions can elicit the information that I need from the instructors in a very non-intrusive way. Third, I used the already designed questionnaire with some adaptation like adding and removing some questions. I find it effective. (L30)

This analysis suggests a way that the respondents designed research methods and selected data collection instruments for their research projects - a way that sought convenient and harmonious strategies in conducting research. These strategies help them deal with time constraints, ease in data collection and analysis, size of samples, and coverage of topics under investigation. These teachers appeared to be apt to undertake research adhering to surveys rather than deep examination of research topics of their interest. Although interview is the most reported research instrument, in fact, the respondents' comments in the questionnaires reveal that this instrument was reported to have been used mainly to triangulate the data collection as indicated in a mixed methods approach.

Although mixed methods is the respondents' dominant reported approach in the survey, the most actually used method and instrument in the 19 published research papers are a quantitative method and questionnaire. Therefore, it appears that the most common features of research involve a wide scope of the topic being researched, objectivity in data collection, large samples as seen in the adoption of a quantitative approach and questionnaires in actual research papers, and data analysis using descriptive statistics. These features are in line with the commonly reported characteristics of good research provided by language teachers worldwide (Borg, 2009) and by other Cambodian teachers (Moore, 2011a). In this regard, most of the institution's teachers who have adopted research and published research papers in CRLLT appear to perceive research as quantitative rather than qualitative.

\section{Discussion}

From the data analysis, there was an overall increase in the number of research-based presentations by the institution's teachers at the annual CamTESOL Conference from 2005 to 2013. This increase could possibly be caused by a number of many possible factors. First, based on the author's observation and experience as a Cambodian ELT professional, it may be in part due to the increase in the number of teachers who hold postgraduate degrees (i.e., MA in TESOL or MEd) from domestic tertiary institutions or overseas universities. Some of these postgraduate students, having conducted research projects in postgraduate programs, may present research papers at a CamTESOL Conference. Second, this increase could also possibly be explained by individual teachers building research records to secure a pathway to admission to postgraduate (PhD) programs (Moore, 2011b). Third, this increase may result from teachers' interest in taking part in research in order to improve professional practices.

As previously mentioned, Moore (2011b) has observed the development of ELT teacher research in tertiary ELT institutions in Cambodia as these institutions aim to secure institutional status. If the developments at this institution are indicative of a trend for tertiary ELT institutions in Cambodia to pay attention to developing research, ELT teacher research will become a longterm approach for professional development to improve the quality of teaching English at these institutions. It seems plausible that teachers at the institution have joined in research, and their 
participation categories range from innovators to early majority. This seems to indicate the possible increasing growth of ELT teacher research at this institution.

At this initial stage of development, teacher research has encountered some important issues of concern about research practice at the institution. The first important issue could be related to a research practice adopted by the institution. The teachers who receive institutional research grants may present the research at the annual CamTESOL conference, yet, as required by the research unit, they will submit the research papers to CRLLT journal. This practice may result in a lack of published research papers authored by the institution's teachers published in LEiA (or in other ELT journals elsewhere). This way of research practice may neither be productive for improving ELT profesional practices in this institution, as well as in Cambodia widely, nor provide the teachers with opportunities to socialize with a wider research community. The second important issue of concern may be related to teachers' adoption of research methods. The study indicates that a quantitative approach (e.g., the use of a questionnaire as an instrument and descriptive statistics as a data analysis framework) are most fitting in teacher research at this institution. It also indicates that the teachers' adoption of research approaches and instruments may be based upon the possibility that the research projects could be undertaken rather than on research rigor. Thus, it is questionable whether or not the institute's teachers are aware of various data collection techniques and data analysis frameworks that teachers can use in undertaking research in classrooms as suggested by Freeman (1998) and Hopkins (2007). This finding calls for further investigation into this area in order to have a clear view of teacher research undertaken by these teachers. Thus, teacher research practice at the institution needs attention for further development. To achieve this aim is to choose an appropriate, yet effective and practical model as a framework for implementing research. Drawing upon Wenger's (2006) notion of communities of practice, to sustain research, teachers need to be intentionally and actively involved in undertaking research. If they are mutually engaged in doing research and learning to do research together, they will create opportunities for learning, that is, learning to teach by undertaking research in their own contexts.

\section{Limitations}

The analysis of teachers' adoption of research revealed in this study is grounded in the information responded by only 37 active teachers. As noted earlier, 26 teachers did not respond to the questionnaire. Moreover, 30 other teachers were on leave for overseas studies. It is, therefore, unclear whether these 56 teachers were involved in research during this period. Furthermore, this survey only asked the teacher participants to self-categorize their research involvement at the institution into one of Rogers' (2003) five adoption categories (see Figure 1) through the questionnaires. The findings show that 25 teachers self-categorized their research engagement into innovators, early adopters, and early majority, but 27 teachers reported to have undertaken research. These different figures could possibly be understood in a way that two teachers may have done research elsewhere rather than in the institution. Moreover, it is uncertain whether those five lecturers who self-categorized as laggards had not been involved in undertaking research activities elsewhere. The survey did not deeply explore the teacher participants' actual research activities and rationale for adopting the innovation of research, especially the five reasons for adoption suggested by Rogers (2003), which could be helpful for further improving the diffusion of the innovation of research in ELT. Therefore, further research in this area should be undertaken, and any future research done in this area should be grounded in qualitative data (i.e., through interactive interviews), and preferably in ethnographically informed data (Moore, 2011a). 


\section{Conclusion}

In conclusion, the teachers' engagement in research at the institution has generally increased since the establishment of CamTESOL in 2005 and the institution's research unit in 2007. An expected number of the institution's teachers appears to have adopted the innovation of teacher research introduced to them and to have been involved in undertaking research, presenting the research, and publishing the research papers. The teachers' self-categorization of adoption of research sugests plausible development in the practice of research at this institution. If the aim is to create a research community, following Wenger's (2006) notion of communities of practice, these teachers who self-categorized as innovators (3 teachers) early adopters (12 teachers) and early majority (10 teachers) are potential primary members to develop a research culture.

As noted earlier, this paper reports on only part of a large $\mathrm{PhD}$ research project. It thus serves as a preliminary report on the development of ELT teacher research in ELT education in this context. A broad, deep, and appropriate understanding about contemporary ELT teacher research at this institution in particular and in Cambodia more widely, with implications for other contexts where research is an innovation, will be realized when this research project is complete.

\section{Author Note}

Chan Narith Keuk, Institute of Foreign Languages, Royal University of Phnom Penh, Phnom Penh, Cambodia.

Chan Narith Keuk is a lecturer of Applied Linguistics and Teaching Methodology at the Institute of Foreign Languages, Royal University of Phnom Penh. His research interests include the variety of English used in Cambodia, the study of English language teachers, and English language teaching education in an EFL context.

This paper is based on a PhD thesis conducted at Macquarie University, Sydney, Australia. I would like to sincerely thank my supervisor, Dr. Stephen Moore, for his valuable guidance and feedback on my paper. I also thank the teachers who voluntarily took part in a profile survey, the data of which were included in this paper.

Correspondence concerning this article should be addressed to Chan Narith Keuk, Institute of Foreign Languages, Royal University of Phnom Penh, Russian Federation Boulevard, Toul Kork, Phnom Penh, Cambodia. E-mail address: keukrith@gmail.com 


\section{References}

Allwright, D. (1997). Quality and sustainability in teacher-research. TESOL Quarterly, 31(2), 368-370. http://dx.doi.org/10.2307/3588054

Allwright, D. (2005). Developing principles for practitioner research: The case of exploratory practice. The Modern Language Journal, 89(3), 353-366. http://dx.doi.org/10.1111/j.1540-4781.2005.00310.x

Barkhuizen, G. (2009). Topics, aims, and constraints in English teacher research: A Chinese case study. TESOL Quarterly, 43(1), 113-125. http://dx.doi.org/10.1002/j.15457249.2009.tb00231.x

Borg, S. (2006). Conditions for teacher research. English Teacher Forum 44(4), 22-27.

Borg, S. (2009). English language teachers' conceptions of research. Applied Linguistics, 30(3), 358-388. http://dx.doi.org/10.1093/applin/amp007

Borg, S. (2010). Language teacher research engagement. Language Teaching, 43(4), 391-429. http://dx.doi.org/10.1017/S0261444810000170

Borg, S. (2013). Teacher research in language teaching: A critical analysis. Cambridge, UK: Cambridge University Press.

Borg, S., \& Liu, Y. (2013). Chinese college English teachers' research engagement. TESOL Quarterly, 47(2), 270-299. http://dx.doi.org/10.1002/tesq.56

Burns, A., \& Burton, J. (2008). Language teacher research in Australia and New Zealand. In A. Burns \& J. Burton (Eds.), Language teacher research in Australia and New Zealand (pp. 1-8). Alexandria, VA: Teachers of English to Speakers of Other Languages.

CamTESOL Conference Series. (2005). Conference program: $1^{\text {st }}$ CamTESOL Conference on English language teaching. Phnom Penh, Cambodia: IDP Education (Cambodia).

CamTESOL Conference Series. (2013). 2013 Conference. Retrieved from http://www.camtesol.org/past-conferences/2013-conference

Clayton, T. (2006). Language choice in a nation under transition: English language spread in Cambodia. Lexington, VA: Springer.

Cochran-Smith, M., \& Lytle, S. L. (1999). The teacher research movement: A decade later. Educational Researcher, 28(7), 15-25. http://dx.doi.org/10.3102/0013189X028007015

Freeman, D. (1998). Doing teacher research: From inquiry to understanding. Toronto, Canada: Heinle \& Heinle.

Gao, X., Barkhuizen, G., \& Chow, A. W. K. (2011). Research engagement and educational decentralisation: Problematising primary school English teachers' research experiences in China. Educational Studies, 372), 207-219. http://dx.doi.org/10.1080/03055698.2010.506338

Hopkins, D. (2008). A teacher's guide to classroom research $\left(4^{\text {th }}\right.$ ed.). Berkshire: Open University Press. McGraw Hill.

Mahony, P. (2011). Acknowledgements. In R. Stroupe \& K. Kimura (Eds.), English language teaching practice in Asia: Editors' choice of selected papers from the CamTESOL Conference Series (2005-2009) (pp. v-vii). Phnom Penh: IDP Education.

Ministry of Education, Youth and Sport. (n.d.). Educational Strategic Plan 2009-2013. Retrieved from http://www.moeys.gov.kh/index.php/en/home/policies-and-strategies/esp-20092013\#.UsZIC_QW2oM

Moore, S. (2011a). Cambodian English teachers' conceptions of and engagement with research. Selected proceedings of the International Conference: Doing research in applied linguistics (pp. 83-98). Bangkok, Thailand: School of Liberal Arts, King Mungkut's University of Technology Thonburi.

Moore, S. (2011b). The struggle to develop a "research culture" in a developing country. TESOL Quarterly, 45(2), 334-343. http://dx.doi.org/10.5054/tq.2011.254525

Moore, S., \& Bounchan, S. (2010). English in Cambodia: Changes and challenges. World Englishes, 29(1), 114-126. http://dx.doi.org/10.1111/j.1467-971X.2009.01628.x 
Nunan, D. (1997). Developing standards for teacher-research in TESOL. TESOL Quarterly, 37(2), 365-367. http://dx.doi.org/10.2307/3588053

Pham, H. H. (2006). Researching the research culture in English language education in Vietnam. TESL-EJ, 1O(2), 1-19. Available at http://www.teslej.org/wordpress/issues/volume10/ej38/ej38a10/

Rogers, E. M. (2003). Diffusion of innovations (5th ed.). New York, NY: Free Press.

Wenger, E. (1998). Communities of practice: Learning, meaning, and identity. Cambridge: Cambridge University Press.

Wenger, E. (2006). Communities of practice: A brief introduction. Retrieved from www.ewenger.com/theory 


\section{Appendix \\ A Survey Profile Questionnaire}

(An introduction which comprises the information about the institution is omitted. This survey profile investigated the teachers' participation in research between 2007 and 2012.)

\section{A. Personal Information}

1. How long have you worked for the institution? years

2. In what year did you begin?

3. What degree(s) do you hold? Please place a cross $(X)$ in the appropriate box (or boxes if you hold more than one degree).
Bachelor degree
Graduate diploma
Master degree
$\mathrm{PhD}$
Others (please specify

\section{B. Participation in ELT Teacher Research at the Institution}

Rogers (2003) proposes five adoption categories to account for a community's members who have responded to an innovation. These five categories comprise (1) innovators; (2) early adopters; (3) early majority; (4) late majority; and (5) laggards. Below are brief descriptions of each adoption category.

Innovators: $\quad$ They have initiated and organized research at the institution.

Early adopters: $\quad$ They have immediately adopted and engaged in research at the institution.

Early majority: $\quad$ They're often reluctant to accept the innovation. It takes them long time to decide to engage in research at the institution.

Late majority: $\quad$ They are sceptical and cautious about research. They've been involved in research only after they've seen other lecturers' successful results.

Laggards: $\quad$ They're uncertain about research and fear failure when they join the activity. They usually perceive their role as teachers only.

In which adoption category would you locate yourself in order to indicate your participation in ELT teacher research at the institution? Please answer the question by placing a cross $(X)$ in the appropriate box below. Choose ONLY one category.

Innovators

Early adopters

Early majority

Late majority

Laggards

\section{Research Experiences}

\section{Please answer the following questions.}

1. Have you conducted any research?

YES (if YES, please continue to question 2)

$\mathrm{NO}$ (if NO, please return the questionnaire to pigeonhole 116. Thanks.) 
2. What research approach did you adopt? (Please choose ONE answer)

Quantitative research approach

Qualitative research approach

Mixed quantitative and qualitative research approach

3. What research instruments did you use for data collection? (Please indicate all instruments you used)

Questionnaires

Structured interviews

Semistructured interviews

Unstructured interviews

Focus groups

Classroom observations

Narrative frames

Field notes

Diary writing

Others (please specify:

4. Could you please provide reasons for the research instruments you selected?

Please return the questionnaire to pigeonhole 116 in the copy room.

Thanks. 